\title{
THE ROLE OF EXCHANGE RATES IN NON-OIL EXPORT ACTIVITY: EVIDENCE FROM AZERBAIJAN
}

\author{
Fuad A. Ganbarov \\ Azerbaijan National Academy of Sciences, Baku, Azerbaijan \\ Gunay T. Alieva \\ Azerbaijan National Academy of Sciences, Baku, Azerbaijan \\ Isgender V. Babazade \\ Azerbaijan State University of Economics, Baku, Azerbaijan
}

\begin{abstract}
The dependence of the Azerbaijani economy on oil makes urgent the issue of diversifying the economy to increase its competitiveness. This, in turn, necessitates the formation of techniques to qualitatively assess the effectiveness of diversification to alternative, namely non-oil exports. This study aims to develop an econometric model to assess the impact of non-oil export diversification on Azerbaijan's economic development. Based on the literature analysis and using hierarchy analysis by T. Saaty, a list of indicators has been proposed to assess the diversification of non-oil exports. The opinions of 30 experts were used to prioritize the indicators. An integral coefficient of diversification of non-oil exports was modelled based on an additive convolution of diversification indicators, taking into account the coefficients of their significance and expert assessments for the priority of indicators. The integral indicator was calculated using the monthly values of Azerbaijan's non-oil export diversification indicators for 2017-2019. Using the fuzzy sets method, the levels of diversification of non-oil exports were determined based on the values of the integral indicator. A multifactorial nonlinear regression model was developed to measure the impact of the diversification of non-oil exports on the country's economic development level. The research results can serve as a suggestion as to the formation of an effective strategy for the modernization of the country's economy.
\end{abstract}

Keywords: non-oil export, economy, diversification, Azerbaijan, oil dependence, competitiveness

DOI: http://dx.doi.org/10.15549/jeecar.v7i3.477

\section{INTRODUCTION}

Azerbaijan is one of the largest producers of crude oil in the world. According to Index
Mundi in 2019 it was ranked 23rd in terms of crude oil volume $(798,000 \mathrm{bbl} /$ day) (Index Mundi, 2020a) and was a leading exporter of 
crude oil worldwide with a volume of 718,800 $\mathrm{bbl} / \mathrm{day}$ (Index Mundi, 2020b). This has predetermined a certain specificity of the importance of crude oil to the country's national economy (almost 40\% of GDP falls is in the oil and gas sector), the development of which is largely determined by the volatility of crude oil prices (The State Statistical Committee of the Republic of Azerbaijan, 2020). Oil revenues have had a significant impact on the entire economy and environmental conditions, including its social sphere (Gulaliyev et al., 2019)

Consequently, the volatility of surplus profits for Azerbaijan is determined not by the volume of production, but by the oil market, over which the country cannot exert any influence. The international rating agency S\&P Global Rating (2020) predicted a decrease in Azerbaijan's GDP growth in 2020 by $6.9 \%$ due to a decrease in the global demand of fuel, the spread of the coronavirus, the emerging global crisis of overproduction, and the oil price war between Saudi Arabia and Russia (Evstratov, 2020). Azerbaijan already once faced a drop in oil prices in 2014-2015, which led to a sharp devaluation of the manat (national currency); it fell by more than half (CESD, 2015). It should be noted, too, that Azerbaijan's dependence on oil negatively affects the country's economic development (Gurbanov, Nugent, \& Mikayilov, 2017). Azerbaijan's narrow-profile diversification of commodity exports created a limited ability to produce more technologically advanced intermediate and final goods, which in turn is the cause of its economy's chronic backwardness. Reforms towards countercyclical support for the economy by improving the business environment (Gulaliyev et al., 2017) and diversifying the economy (exports in general, and especially increasing the scale and diversification of non-oil exports) were, as a result, needed. Thus, the priority of export diversification has been noted in the basic provisions of the Development Concept "Azerbaijan-2020: a look into the future" (2012), the "State Program on the development of industry in the Republic of Azerbaijan in 2015-2020" (2014) and correlates with the main characteristics of the export-oriented production target model of Azerbaijan's economic development. The transformation of the vector of development of non-oil exports has been reflected in the changes introduced by the Cabinet of Ministers of Azerbaijan to The Commodity Nomenclature of Foreign Economic Activity of the Republic of Azerbaijan, and to the rates of import and export customs duties (2020). Export diversification contributes to increasing production in the non-oil sector and exporting competitive products. The cumulative impact of improvements in the legislative framework and changes in the geopolitical and global economic landscape necessitated increasing non-oil exports in the country's export structure. In the first half of 2020, non-oil exports have increased by $12.69 \%$ compared to the same period in 2019 (The State Statistical Committee of the Republic of Azerbaijan, 2020).

It should be noted, though, that diversifying the export potential of non-primary commodities has proved to be a difficult task for Azerbaijan. Due to the inefficiency of the state's industrial policy, the structural transformation of exports comes mainly from the agricultural sector directly to the service sector. Consequently, most of the domestic valueadded comes from the service sector. The export basket, as before, remains concentrated on basic commodities (The State Statistical Committee of the Republic of Azerbaijan, 2020), which is why it can be argued that there is a low level of export diversification in Azerbaijan today. For the reasons provided above, our study aims to identify the features of the impact of diversification of the country's non-oil exports on the development of its economy using an empirical basis.

\section{LITERATURE REVIEW}

The specificity of the influence of the structure of the export basket on economic development indicators has been attracting the attention of scientists for a long time and provoking serious scientific discussions of various points of view. The key concept of export diversification is to substantiate its positive impact on the national economy's key indicators, especially concerning long-term development prospects. The position of D. Ricardo has become the foundation for numerous modern studies in the field of international trade, as well as the statement about the direct proportionality of the growth of economic incomes from the level of export 
specialization (Watson, 2017). Many empirical studies have shown that diversifying trade exports is critical to preventing volatility in export growth and productivity growth (Lee \& Yu, 2019; Del Rosal, 2019; Mania \& Rieber, 2019). The increasing diversification of exported goods is believed to positively affect firm value compared to expanding product diversification in domestic markets (Kwon, 2017). This allows for more dynamic growth-enhancing benefits such as facilitating the disclosure of costs and demand and faster and more diversified accumulation of opportunities and other productive resources.

Recently, the study of export diversification and its advantages over specialization has become relevant in terms of leveling the risks of fluctuations in the national economy under the impact of external shocks resulting from the portfolio effect (De Oliveira, Jegu \& Santos, 2020). Thus, it is interesting to research the diversification of exports and their impact on the economies of countries with resourceoriented exports. Most scholars believe that the specialized export basket of oil-exporting countries makes them extremely vulnerable to price shocks in the global market (Shayah, 2015). And the efficiency of export and economic diversification is not naturally predetermined with population, government effectiveness, or democratic accountability, but is conditioned by a lower level of oil reserves (Ross, 2019). That is primarily due to the effect of the 'Dutch disease'. In case of population with a high level of income, export specialization provides higher level of economic growth, which is more important than export diversification (Cadot, Carre \& Strauss-Kahn, 2011). Therefore, it can be concluded that less economically developed countries achieve high and sustainable development rates only due to the expansion of export diversification. These differences are also associated with crosscountry differences in financial development and structure (Nieminen, 2020). The need for diversification has also been supported by scientists studying the 'middle-income states' problem, explaining that the significant share of technological exports in the total structure of the export volume reduces the likelihood of the economy falling into the middle-income pit (Lee, 2018).
Numerous scholars also tend to have an opposite perspective regarding the key role of diversifying the export structure. Arguments against it have been based on the fact that increased diversification of export baskets conflicts with comparative advantage theory (Lee \& Yu, 2019). Following this theory, the provision of high growth rates can be achieved using export specialization in only few certain sectors. There is also a point of view in the scientific literature that the absolute dominance of the oil industry in the structure of exports (in countries dependent on oil) affects the diversification of exports negatively only if countries initially demonstrate a low level of export diversification (Djimeu \& Omgba, 2019). In countries with high diversification levels before an oil boom, oil dependence has no significant effect on changes in economic growth. Moreover, diversification of export markets rather than diversification of products is a more effective method to mitigate the negative impact of global economic crashes (Shayah, 2015). This suggests that it is imperative to expand export markets to countries with high growth potential while maintaining export competitiveness in each industry.

A variety of approaches can be found in the current literature on the toolkit for assessing the impact of export diversification (Le et al., 2020; Rath \& Akram, 2017; Shadab, 2020; Hinlo \& Arranguez, 2017; Mania \& Rieber, 2019; De Oliveira, Jegu \& Santos, 2020). Most of them described causal relationships based on the linear connection between economic diversification and efficiency (Rath \& Akram, 2017; Shadab, 2020; Hinlo \& Arranguez, 2017). Also, a further literature review proves the different nature of the qualitative connection and the move toward the diversification of exports to the economy, depending on the level of diversity of the exported goods, the level of development of the country's economy, and the characteristics of the resource model of the national economy and the diversification of non-oil exports. Besides, a prevailing number of scientific papers discusses the perspective of a certain indicator of international trade and diversification (Hinlo \& Arranguez, 2017; Lee \& Yu, 2019; Del Rosal, 2019; Mania \& Rieber, 2019; De Oliveira, Jegu \& Santos, 2020; Kim, 
2019). Given the existing inaccuracies and controversial aspects of the methodology, within the framework of this study an attempt was made to substantiate the impact of export diversification.

\section{METHODS AND MATERIALS}

The assessment of the impact of diversification of non-oil exports for the economic development of Azerbaijan was carried out in 4 stages.

\section{Stage 1. Determination of indicators to assess the diversification of non-oil exports.}

Using the generalized system of international trade indicators (Lee \& Yu, 2019; Hinlo \& Arranguez, 2017; Del Rosal, 2019; Mania \& Rieber, 2019; De Oliveira, Jegu \& Santos, 2020) of Azerbaijan and the hierarchy analysis method T. Saati, we assessed the representativeness of each of the international trade indicators to determine which is most significant in the diversification of international trade. The use of quantitative methods (regression, discriminant analysis) for this purpose was impossible due to the absence of a generally accepted resultant indicator characterizing the diversification and levels of export diversification quantitatively.

The expert group for assessment was formed by 30 representatives of the Trend International Information Agency (2020) in Azerbaijan. The experience of each expert in the field of the analytical assessment of international trade (more than 5 years) ensures the competence of the expert group and the adequacy of assessment results. Each expert independently (without meeting with other representatives of the expert group) put forward pairwise estimates of the relative importance of indicators for all pairs of indicators. Estimates $\left(a_{i j}\right)$, according to T. Saaty's method, were deterministic in the range from 1 to 9 points, where:

1 - the same significance comparing the pair of indicators;

3 - moderate dominance of the importance of the $i$-th indicator to the $j$ - $t h$;

5 - significant dominance of the $i$-th indicator to the $j$-th;
7 - significant dominance of the $i$-th indicator to the $j$-th;

9 - the hight strong dominance of the importance of the $i$-th indicator to the $j$ - $t h$;

$2,4,6,8$ - corresponding intermediate values.

The significance of export diversification indicators has been estimated by the formula (Kudláč, Štefancová, and Majerčák, 2017):

$$
w_{i}=\frac{\sqrt[n]{\prod_{i=1}^{n} a_{i j}}}{\sum_{i=1}^{n} \sqrt[n]{\prod_{i=1}^{n} a_{i j}}},
$$

Where $w_{i}$ - significance of the $i$-th indicator;

$a_{i j}$ - value of the dominance of the $i$-th indicator over the $j$-th;

$n$ - number of indicators.

The selection of representative indicators of Azerbaijan's international trade was carried out using the criterion of the significance of the principal component method with the level of the total percentage of factorization $>80 \%$ (if $\sum_{i=1}^{k} w_{i} \geq 0.8$, where $k$ - number of indicators ranked in decreasing order to importance).

Stage 2. Construction of an integral diversification indicator of non-oil exports

The presence of a certain number of significant private diversification indicators of trade exports $(k \neq 0 \quad U \quad k \neq 1)$ necessitates a comprehensive study of diversification taking into account these indicators. For this purpose, and within the framework of this study, the method of integral assessment was used (Vasiljeva et al., 2020):

$$
I=\sum_{i=1}^{k} w_{i} \times Z_{i},
$$

Where $I$ - integral diversification indicator of trade exports;

$Z_{i}$ - standardized value of the $i$-th indicator;

$k$ - number of representative indicators. 
To ensure the commensurability of diversification indicators of non-oil exports and the adequacy of the assessment results, the indicators were standardized using formula (3) for stimulating indicators (an increase in which indicates an increase in the diversification of non-oil exports) and formula (4) for indicatorsdisincentives (an increase in which indicates the concentration of non-oil export) (Neskorodeva \& Pustovgar, 2015; Anysz, Zbiciak \& Ibadov, 2016):

$$
\begin{aligned}
Z_{i} & =\frac{X_{i}-X_{i \min }}{X_{i \max }-X_{i \min }} \\
Z_{i} & =\frac{X_{i \max }-X_{i}}{X_{i \max }-X_{i \min }},
\end{aligned}
$$

Where $X_{i}$ - the actual value of the $i$-th diversification indicator of non-oil exports;

$X_{i \min }$ and $X_{i \max }$ - the minimum and maximum value of the $i$-th diversification indicator of non-oil exports;

To construct the integral indicator, the monthly data of Azerbaijan's trade exports for all product groups, except for the export of mineral fuel, oil, and refined products, for the period from 2017 to 2019 were used (The State Statistical Committee of the Republic of Azerbaijan, 2020).

\section{Stage 3. Determination of the diversification of non-oil exports}

The diversification levels of non-oil exports (indicator $I$ levels) were determined using the fuzzy set method with a trapezoidal classification function. The numerical boundaries of the integral indicator corresponding to the zone of $100 \%$ confidence in the classification of fuzzy sets were determined using the actual values of the indicator $I$ for 2017-2019, and levels were supplemented by the minimum and maximum possible values of the integral indicator $(0$ and 0.824 , respectively). The diversification levels were identified taking into account the Student's tcriterion and maximizing the empirical value of the criterion:

$$
\begin{aligned}
& \mu_{1}=\left\{\begin{array}{l}
1, I_{\text {min }} \leq I \leq I\left(t_{1}\right) \\
\frac{I\left(t_{2}\right)-I}{I\left(t_{2}\right)-I\left(t_{1}\right)}, I\left(t_{1}\right)<I<I\left(t_{2}\right) \\
0, I\left(t_{2}\right) \leq I \leq I_{\max }
\end{array}\right. \\
& \mu_{2}=\left\{\begin{array}{l}
0, I_{\min } \leq I \leq I\left(t_{1}\right), I\left(t_{4}\right) \leq I \leq I_{\max } \\
\frac{I-I\left(t_{1}\right)}{I\left(t_{2}\right)-I\left(t_{1}\right)}, I\left(t_{1}\right)<I<I\left(t_{2}\right) \\
\frac{I\left(t_{4}\right)-I}{I\left(t_{4}\right)-I\left(t_{3}\right)}, I\left(t_{3}\right)<I<I\left(t_{4}\right) \\
1, I\left(t_{2}\right) \leq I \leq I\left(t_{3}\right)
\end{array}\right. \\
& \mu_{3}=\left\{\begin{array}{l}
0, I_{\min } \leq I \leq I\left(t_{3}\right) \\
\frac{I-I\left(t_{3}\right)}{I\left(t_{4}\right)-I\left(t_{3}\right)}, I\left(t_{3}\right)<I<I\left(t_{4}\right) \\
1, I\left(t_{4}\right) \leq I \leq I_{\max }
\end{array}\right.
\end{aligned}
$$

Where $\mu_{1}$ - the probability of attributing indicator $I$ to a low level, $\mu_{2}$ - to an average, $\mu_{3}$ to a high;

$I_{\min }, I_{\max }$ - minimum and maximum value of the index $I$;

$\left[I_{\text {min }} ; I\left(t_{1}\right)\right],\left[I\left(t_{2}\right) ; I\left(t_{3}\right)\right],\left[I\left(t_{4}\right) ; I_{\max }\right]$ - levels of the indicator $I$ with differences statistically significant by the $t$-test.

Stage 4. Assessment of the impact of diversification of non-oil exports to the economic development of the country

To assess the impact of non-oil export diversification on the country's economic development, the method of one-factor linear, non-linear regression, VAR-model was used. The indicator of the dynamics of GDP per capita in US dollars (chain growth rate relative to the corresponding month of the previous year for 2017-2019) was used as a dependent variable in these models (The State Statistical Committee of the Republic of Azerbaijan, 2020). The calculated values of the integral diversification indicator of non-oil exports were used as an independent variable. The analytical base for modeling was aggregated based on monthly data for 2017-2019.

Econometric models were developed using the Statistica 12.0 and EViews 10 software packages. The statistical adequacy of the models was argued using Fisher's F-test, Student's ttest, and the deviation of the dependent variable from the actual for 2017-2019. The smallest prediction error was determined by the 
nonlinear regression model, which was used to assess the impact of diversification of non-oil exports on the country's economic development.

\section{RESULTS}

A generalized matrix of the significance of indicators for assessing export diversification was formed based on the expert assessment results (Appendix A). According to the matrix, the most significant indicator to assess the diversification of non-oil exports was the Herfindahl index, the average priority of which was 0.207 for the expert group. This was an indicator that reflects the sum of the squares of the share of each commodity nomenclature in the structure of non-oil exports. The second most important indicator was Theil's entropy index, which assesses the contribution of various components and their groups to the total unevenness. The significance of this indicator was - 0.166. According to experts' estimates, when assessing diversification, the following indicators were significant:

Share of the 5 of 10 main export products (commodity groups) in non-oil exports, \% (the significance was 0.131 and 0.070 , respectively);

The number of non-oil export commodity groups for which the export value is > 50 million USD and the number of non-oil export commodity groups for which the export value is $>10$ million USD (significance 0.088 and 0.055 , respectively);

Entropy index is an indicator that characterizes the average value of the logarithmic quantity inverse to the share of non-oil exports, weighted by category.

The cumulative assessment of the significance of these indicators was 0.824 , which indicated the representative of indicators as the criterion $\sum_{i=1}^{k} w_{i} \geq 0.8$. Therefore, other indicators were not taken into account in the article. The representativeness of the results of the expert assessment regarding the determination of the significance of indicators of diversification of non-oil exports was proven by:

- concordance factor 0.84 ;

- the value of the consistency index did not exceed 0.13 (with the maximum allowable $0.2)$;
- the values of the consistency ratio said not exceed 0.08 (with the maximum allowable $0.1)$.

A representative list of indicators to assess the diversification of non-oil exports was formed by the Herfindahl index, Theil's entropy index, Share of the 5 main export products (commodity groups) in non-oil exports, Share of the 10 main export products (commodity groups) in non-oil exports, the Entropy index, The number of non-oil export commodity groups for the export value is > 50 million USD, and the number of non-oil export commodity groups for he export value is $>10$ million USD.

Taking into account the system of indicators of trade exports, an integral model was developed for assessing the degree of diversification of non-oil exports:

$$
\begin{aligned}
& \mathrm{I}=0.207 \times Z_{H H I}+0.166 \times Z_{T I}+0.131 \times \\
& Z_{S h .5}+0.106 \times Z_{E I}+0.088 \times Z_{N .50}+ \\
& 0.07 \times Z_{S h .10}+0.055 \times Z_{N .10}
\end{aligned}
$$

Where $Z_{H H I}$ - standardized Herfindahl index values;

$Z_{T I}$ - standardized Theil's entropy index values;

$Z_{S h .5}$ - standardized values of the indicator Share of the 5 main export products (product groups) in non-oil exports;

$Z_{E I}$ - standardized Entropy index values;

$Z_{N .50}$ - standardized values of the indicator The number of non-oil export commodity groups for the export value > 50 million USD;

$Z_{S h .10}$ - standardized values of the indicator Share of the 10 main export products (product groups) in non-oil exports;

$Z_{N .10}$ - The number of non-oil export commodity groups for the export value $>10$ million USD.

Depending on the nature of the impact, export diversification indicators were ranked into stimulant indicators (TI, EI, N.10, N.50) and discouraging indicators ( $H H I, S h .5, S n .10)$. But in the proposed integral model (formula 6) all weighted indicators were summed up because they have been standardized (Table 1) 
Table 1: Values of the integral indicator of diversification of non-oil exports of Azerbaijan for 20172019

\begin{tabular}{|l|l|l|l|l|l|}
\hline Period, 2017 & Indicator & Period,2018 & Indicator & Period, 2019 & Indicator \\
\hline January & $0.444^{* *}$ & January & $0.452^{* *}$ & January & $0.388^{*}$ \\
\hline February & $0.508^{* *}$ & February & $0.519^{* *}$ & February & $0.422^{* *}$ \\
\hline March & $0.584^{* * *}$ & March & $0.547^{* *}$ & March & $0.507^{* *}$ \\
\hline April & $0.518^{* *}$ & April & $0.472^{* *}$ & April & $0.448^{* *}$ \\
\hline May & $0.376^{*}$ & May & $0.290^{*}$ & May & $0.303^{*}$ \\
\hline June & $0.320^{*}$ & June & $0.285^{*}$ & June & $0.422^{* *}$ \\
\hline July & $0.595^{* * *}$ & July & $0.469^{* *}$ & July & $0.547^{* *}$ \\
\hline August & $0.599^{* * *}$ & August & $0.498^{* *}$ & August & $0.599^{* * *}$ \\
\hline September & $0.421^{* *}$ & September & $0.521^{* *}$ & September & $0.551^{* * *}$ \\
\hline October & $0.267^{*}$ & October & $0.324^{*}$ & October & $0.314^{*}$ \\
\hline November & $0.219^{*}$ & November & $0.222^{*}$ & November & $0.342^{*}$ \\
\hline December & $0.423^{* *}$ & December & $0.371^{*}$ & December & $0.432^{* *}$ \\
\hline
\end{tabular}

* - low diversification of non-oil exports;

** - middle low diversification of non-oil exports;

*** - high low diversification of non-oil exports.

Using the calculated values of the integral indicator its levels have been determined:

$$
\begin{aligned}
& \mu_{1}=\left\{\begin{array}{l}
1,0 \leq I \leq 0.388 \\
\frac{0.421-I}{0.033}, 0.388<I<0.421 \\
0,0.421 \leq I \leq 0.824
\end{array}\right. \\
& \mu_{2}=\left\{\begin{array}{c}
0,0 \leq I \leq 0.388 ; 0.551 \leq I \leq 0.824 \\
\frac{I-0.388}{0.033}, 0.388<I<0.421 \\
\frac{0.551-I}{0.004}, 0.547<I<0.551 \\
1,0.421 \leq I \leq 0.547
\end{array}\right. \\
& \mu_{3}=\left\{\begin{array}{c}
0,0 \leq I \leq 0.547 \\
\frac{I-0.547}{0.004}, 0.547<I<0.551 \\
1,0.551 \leq I \leq 0.824
\end{array}\right.
\end{aligned}
$$

Zones of $100 \%$ confidence in the classification of fuzzy sets corresponded to the values of the integral indicator with a low diversification of non-oil exports $[0 ; 0.388]$, middle level [0.421;0.547], a high level - [0.551;0.824]. According to these levels, Azerbaijan's non-oil exports were characterized mainly by an average level of diversification (during JanuaryFebruary, April, September, December 2017; January-April, July-September 2018; FebruaryApril, June-July, December 2019). A low level of diversification was inherent mainly throughout
2018 (May-June, October-December). A high level of diversification was observed in 2017 (March, July-August) and 2019 (AugustSeptember).

The main commodity items of Azerbaijan's non-oil exports are: herbal products, part of which in non-oil exports amounted to 34.1 $36.3 \%$ for $2017-2019$; precious metals and the products from them - 12.6 - 16.9\%; pearls, precious or non-precious stones, precious metals and articles thereof, jewelry, coins - 9.19.7\%; plastics, rubber, rubber products from the - 7.1-9.8\%; textile materials and products - 5.3$10.1 \%$ (The State Statistical Committee of the Republic of Azerbaijan, 2020).

To influence the degree of diversification of non-oil exports on the efficiency of the country's economic development, a non-linear regression model was developed:

$$
Y=1.2464 \times I^{2}-1.1695 \times I+1.3299
$$

where $Y$ - GDP growth rate per capita.

The empirical value of the F-criterion for the constructed model was 97.4 , tabular $F(2,33)$ at a significance level of $0.05-3.32$. The empirical value of the t-test for $I^{2}-4.07, I-(-4.46)$, tabular 
$t$ (33) at a significance level of $0.05-2.0345$. The deviation of the calculated values of the dependent variable from the actual ones did not exceed $5 \%$ and indicated the adequacy of the model. The regularity of the influence of the level of diversification of non-oil exports on the dynamics of economic development is shown in Fig. 1.

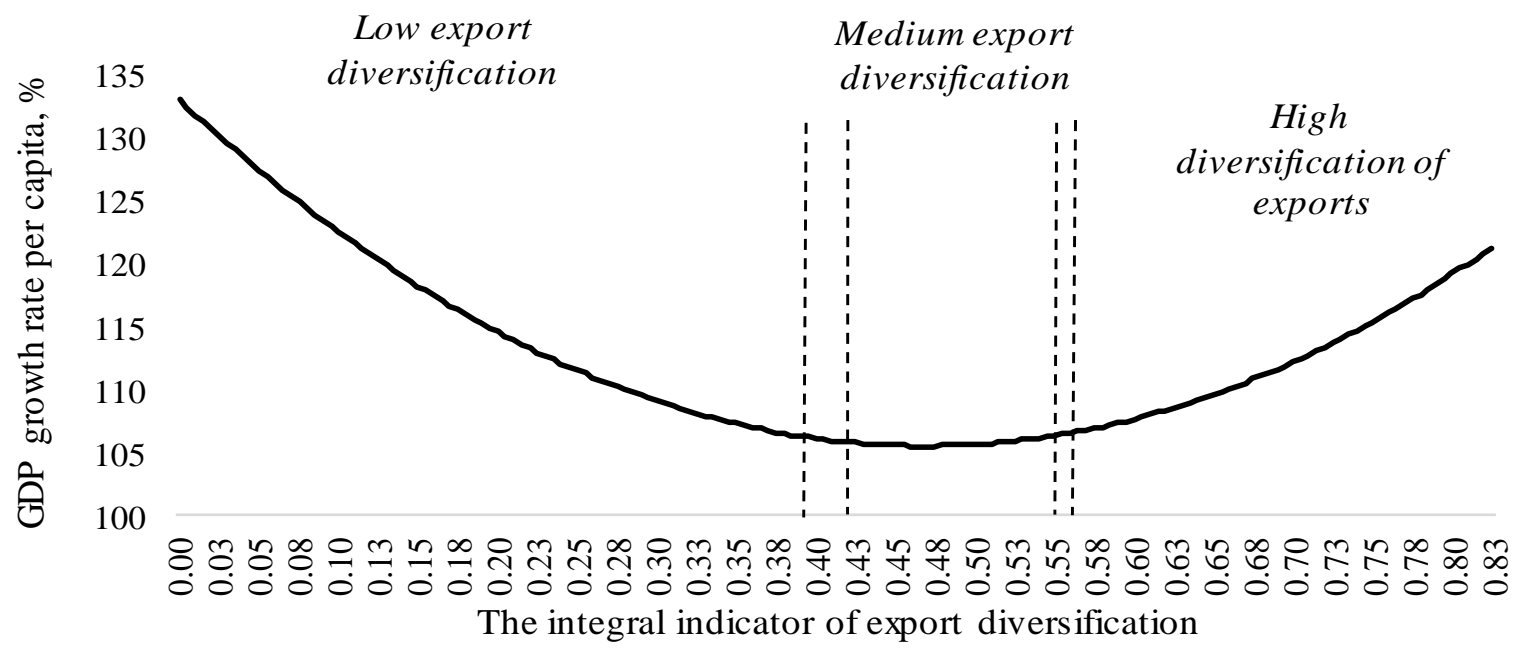

Figure 1: Integral dynamics of the economic development of Azerbaijan according to the diversification of non-oil exports for 2017-2019

As a result of constructing the model, the following pattern was revealed: with a low level of diversification of non-oil exports, an increase in diversification leads to a decrease in economic development, the minimum level of which has been observed for an average level of export diversification. A further increase in the degree of diversification leads to sustainable economic growth.

For Azerbaijan, the integral indicator of diversification of non-oil exports was in the range $[0.219 ; 0.599]$. The minimum level of diversification corresponded to the value of the rate of growth of GDP per capita 1.13, the maximum - 1.08. At the same time, a further decrease in the integral indicator of diversification by 0.1 in comparison with the minimum value would lead to an increase in GDP per capita by $20.85 \%$; an increase in the diversification indicator by 0.1 in comparison with the maximum value would lead to an increase in GDP per capita by $12.16 \%$. The potential growth of GDP per capita with a minimum level of diversification was 32.99\%, the potential growth with the maximum level of diversification was $21.34 \%$.

\section{DISCUSSION}

The proposed empirical model for the integral assessment of export diversification, in contrast to those approaches based on partial indicators (Hinlo \& Arranguez, 2017; Lee \& Yu, 2019; Del Rosal, 2019; Mania \& Rieber, 2019; De Oliveira, Jegu \& Santos, 2020; Kim, 2019) allows for: assessing the degree of diversification based on the share of Top-5/10 exported goods (product groups) comprehensively; the number of product groups with monthly export volumes exceeding 10/50 million US dollars; the share of each commodity nomenclature in the structure of non-oil exports. At the same time, the resulting integral assessment is available for interpretation and does not need a separate analysis of each particular indicator. The levels of the integral indicator allow the assessment of the level of diversification of non-oil exports quantitatively and qualitatively. The advantages of the proposed approach to determining the levels of diversification are to take into account the entire range of values of the integral indicator (due to the addition of the minimum and maximum possible value of the integral indicator). In this case, it is possible to take into 
account the current state of exports (because the levels are determined based on the actual data of the integral indicator). The use of the method of fuzzy sets, in contrast to (Kim, 2019), allows us to more accurately diagnose the level of diversification due to the presence of zones of $100 \%$ confidence and intermediate values. Also, the developed econometric model provides a quantitative and qualitative characteristic of the level of diversification of non-oil exports and its impact on economic development, taking into account the nonlinear properties of communication, which will allow for a more objective assessment of impact.

The developed econometric model for diagnosing the impact of export diversification on the development of the Azerbaijani economy has shown the presence of a non-linear relationship, as stated in the works of Rath \& Akram (2017); Shadab (2020); and Hinlo \& Arranguez (2017), but non-linear, since diversification was associated with economic growth with a U-shaped relationship over time. The revealed pattern is explained by the fact that a low level of export diversification means the presence of pronounced absolute advantages of the country in the production of a certain type of good. Absolute advantages lie in the availability of the necessary natural resources, labor, capital resources and specialization in the production of goods, which minimizes production and export costs, thereby ensuring maximum income for the country. The growth of the degree of diversification requires a wider specialization, the availability of a wider range of natural resources, the need for training or retraining of personnel and the acquisition of new technologies, which leads to higher rates of growth in costs compared to income. At the same time, a high level of diversification is a "safety margin", when declining world prices or other unfavorable trading conditions in one market are compensated by incomes in other markets.

\section{CONCLUSION}

Based on the conducted empirical research, the following conclusions can be drawn. Given the current level of development of Azerbaijan's economy, it seems appropriate to ensure the diversification of the country's non-oil exports.
But it should be borne in mind that the impact of diversification has a U-shaped connection with the growth rate of economic development. The developed econometric model for assessing the impact of diversification of non-oil exports has determined the following qualitative characteristics of interaction: with a low level of diversification of non-oil exports, an increase in diversification leads to a decrease in economic development, the minimum level of which was observed for an average level of export diversification. A further increase in the degree of diversification leads to sustainable economic growth. Consequently, the strategy for diversifying non-oil exports in Azerbaijan should be based on the nonlinear dependence of the intensity of economic growth, taking into account the fact that the diversification of nonoil exports ensures economic growth at various levels of its variation. The results obtained have been based on a sample of indicators characterizing the international trade of Azerbaijan, therefore they can only be applied to this country. It should also be noted that the revealed patterns of impact for the diversification of the non-oil export basket to the rates of economic development were considered for two years and, when studied over a longer period, may show other features. Besides, within the framework of this study, only non-oil exports were considered, excluding oil and gas. All these issues are of fundamental importance for the topic under consideration and will be investigated in our future scientific publications.

\section{REFERENCES}

Anysz, H., Zbiciak, A., and Ibadov, N. (2016). The Influence of Input Data Standardization Method on Prediction Accuracy of Artificial Neural Networks. Procedia Engineering, 153, pp. 66-70.

Cadot, O., Carre, C., and Strauss-Kahn, V. (2011). Export Diversification: What's Behind the Hump? The Review of Economics and Statistics, 93(2), pp. 590-605.

CESD. (2015). Devaluation of Azerbaijani National Currency; Causes and Consequences. Retrieved from http://cesd.az/new/wp- 
content/uploads/2015/03/Azerbaijan_Natio nal_Currency_Devaluation2.pdf.

De Oliveira, H.C., Jegu, E., and Santos, V.E. (2020). Dynamics and determinants of export diversification in Brazil from 2003 to 2013. Economy and Society, 29(1). Retrieved from

https://www.scielo.br/scielo.php?pid=S0104 $-06182020000100029 \&$ script=sci_arttext

Del Rosal, I. (2019). Export Diversification and Export Performance by Destination Country. Bulletin of Economic Research, 71(1), pp. 5874.

Djimeu, E., and Omgba, A. (2019). Oil windfalls and export diversification in oil-producing countries: Evidence from oil booms. Energy Economics, 78, pp. 494-507.

Evstratov, A. (2020). Irreplaceable losses in Azerbaijan's economy from oil crisis and coronavirus. Retrieved from https://wgi.world/irreplaceable-losses-inazerbaijan-s-economy-from-oil-crisis-andcoronavirus/.

Gulaliyev, M., Abasova, S., Huseynova, S, Azizova, R., and Yadigarov, T. (2017). Assessment of impacts of the state intervention in foreign trade on economic growth. Revista Espacios, 38(47). Retrieved from https://www.revistaespacios.com/a17v38n4 7/a17v38n47p33.pdf.

Gulaliyev, M., Muradov, R., Hajiyeva, L, Muradova, H., Aghayeva, K., and Aliyev, E. (2019). Study of Human Capital Development, Economic Indicators and Environmental Quality. Ekoloji, 28(107), pp. 495-503.

Gurbanov, S., Nugent, J.B., and Mikayilov, J. (2017). Management of Oil Revenues: Has That of Azerbaijan Been Prudent? Economies, 5, 19. Retrieved from https://www.mdpi.com/2227-7099/5/2/19.

Hinlo, J., and Arranguez, G. (2017). Export Geographical Diversification and Economic Growth among ASEAN Countries, MPRA Paper No. 81333.

Index Mundi. (2020a). Oil - production. Retrieved from https://www.indexmundi.com/g/r.aspx?v=8 8.

Index Mundi. (2020b). Oil - exports. Retrieved from

https://www.indexmundi.com/g/r.aspx?t=0 $\& \mathrm{~V}=95 \& \mathrm{l}=\mathrm{en}$.

Kim, Y.R. (2019). Does aid for trade diversify the export structure of recipient countries? World Economy, 42, pp. 2684-2722.

Kudláč, Š., Štefancová, V., and Majerčák, J. (2017). Using the Saaty Method and the FMEA Method for Evaluation of Constraints in Logistics Chain. Procedia Engineering, 187, pp. 749-755.

Kwon, T. (2017). Valuation Effects of Product Diversification in Export Markets. Korean Journal of Financial Engineering, 16(1), pp. 1-28.

Le, T., Nguyen, C., Su, T., and Tran-Nam, B. (2020). The Kuznets curve for export diversification and income inequality: Evidence from a global sample. Economic Analysis and Policy, 65, pp. 21-39.

Lee, J., and Yu, B. (2019). The Effects of Export Diversification on Macroeconomic Stabilization: Evidence from Korea. KDI Journal of Economic Policy, 41(1), pp. 1-14.

Lee, J.-W. (2018). Convergence success and the middle-income trap. European Bank for Reconstruction and Development. Working Paper N211.

Mania, E., and Rieber, A. (2019). Product export diversification and sustainable economic growth in developing countries. Structural Change and Economic Dynamics, 51, pp. 138-151.

Neskorodeva, I., and Pustovgar, S. (2015). An Approach to Predicting the Insolvency of Ukrainian Steel Enterprises Based on Financial Potential. Journal of Eastern European and Central Asian Research, 2(2), pp. 33-43.

Nieminen, M. (2020). Multidimensional financial development, exporter behavior and export diversification. Economic Modelling, 93, pp. 1-12.

Rath, B., and Akram., V. (2017). Export Diversification and Total Factor Productivity Growth in Case of South Asian Region. 
Journal of Social and Economic Development, 19(1), pp. 196-210.

Ross, L. (2019). What do we know about export diversification in oil-producing countries? The Extractive Industries and Society, 6(3), pp. 792-806.

S\&P Global Rating. (2020). Global Banking Country-By-Country Outlook. Midyear 2020: More Or Less Resilient To COVID-19 Shocks. Retrieved from https://www.spglobal.com/_assets/images/r atings/pdf/global-banking-country-bycountry-outlook-midyear-2020.pdf.

Shadab, S. (2020). Export Diversification and Economic Growth in the United Arab Emirates: An Empirical Investigation. Research Square. Retrieved from https://www.researchsquare.com/article/rs33529/v1.

Shayah, M. (2015). Economic diversification by boosting non-oil exports (case of UAE). Journal of Economics, Business and Management, 3(7), pp. 735-738.

The State Statistical Committee of the Republic of Azerbaijan. (2020). Retrieved from https://www.stat.gov.az/source/system_nat _accounts/?lang=en.

Trend. (2020). News Agency. Retrieved from https://en.trend.az/.

Vasiljeva, M., Neskorodieva, I., Ponkratov, V., Kuznetsov, N., Ivlev, V., Ivleva, M., Maramygin, M., and Zekiy, A. (2020). A Predictive Model for Assessing the Impact of the COVID-19 Pandemic on the Economies of Some Eastern European Countries. Journal of Open Innovation: Technology, Market, and Complexity, 6(3), 92. Retrieved from https://www.mdpi.com/2199-8531/6/3/92.

Watson, M. (2017). Historicising Ricardo's comparative advantage theory, challenging the normative foundations of liberal International Political Economy. New Political Economy, 22(3), pp. 257-272.

State Program on the development of industry in the Republic of Azerbaijan in 2015-2020. (2014). Order of the President of the Republic of Azerbaijan dated December 26, 2014. Retrieved from https://azertag.az/ru/xeber/GOSUDARSTVEN
NAYA_PROGRAMMA_po_razvitiyu_promysh lennosti_v_Azerbaidzhanskoi_Respublike_n a_2015_2020_gody-823447.

Development Concept "Azerbaijan-2020: a look into the future". (2012). Decree of the President of the Republic of Azerbaijan dated 29.12.2012 N800. Retrieved from https://president.az/files/future_ru.pdf.

On amendments to the "Commodity nomenclature of foreign economic activity of the Republic of Azerbaijan, to the rates of import and export customs duties", approved by the Resolution of the Cabinet of Ministers of the Republic of Azerbaijan dated November 17, 2017 № 500. (2020). Resolution of the Cabinet of Ministers of the Republic of Azerbaijan dated 17.02.2020 N44. Retrieved from https://nk.gov.az/ru/document/4271/.

\section{ABOUT THE AUTHORS}

Fuad A. Ganbarov, email: fuad.ganbarov75@gmail.com

Fuad A. Ganbarov is a Doctor of Science in Economics, head of a department in the Institute of Economics of Azerbaijan National Academy of Sciences.

Gunay T. Alieva is a Candidate for PhD degree of the Institute of Economics of Azerbaijan National Academy of Sciences.

Isgender V. Babazade is a Candidate for $\mathrm{PhD}$ degree of the Azerbaijan State University of Economics (UNEC). 